\title{
Tata Kelola Administrasi Dusun Dungsuru Desa Pilangrejo Nglipar Gunungkidul
}

\section{Dungsuru Village Administrative Governance of Nglipar District Gunungkidul Regency}

\author{
${ }^{1 *}$ Suranto, ${ }^{2)}$ Anna Nur Nazilah Chamim, ${ }^{3)}$ Muhammad Iqbal \\ ${ }^{1,2,3)}$ Program Studi Ilmu Pemerintahan, Fisipol, Universitas Muhammadiyah Yogyakarta \\ Jalan Brawijaya, Kasihan, Yogyakarta 55183 \\ *email: suranto@umy.ac.id
}

DOI:

10.30595/jppm.v5i1.9576

Histori Artikel:

Diajukan:

23/01/2021

Diterima:

20/03/2021

Diterbitkan:

30/03/2021

\section{ABSTRAK}

Kegiatan pengabdian masyarakat ini bertujuan untuk (1) mengidentifikasi dan menyusun database dusun Dungsuru yang terintegrasi dan mudah digunakan, dan (2) menyusun dokumen profil desa yang update dan bisa digunakan untuk dasar perencanaan pembangunan desa Pilangrejo, Nglipar, Kabupaten Gunungkidul. Adapun metode pencapaian tujuan tersebut dilakukan melalui pelatihan dengan metode wawancara, dokumentasi dan Focus Group Discussion di tingkat Desa. Hasi kegiatan pengabdian ini menunjukkan bahwa program berlangsung dengan baik dan lancar. Program ini mampu menghasilkan dokumen databse dusun dan profil desa Pilangrejo yang update dan bermanfaat untuk perencanaan pembangunan desa. Adapun kendala yang muncul pada tahap awal kegiatan dapat diatasi dengan metode pendampingan intensif. Adapun saran yang diajukan dari hasil program PPM ini, hendaknya pemerintah desa bisa mengupdate perkembangan database dan profil secara rutin seiring dinamika data yang terjadi.

Kata kunci: Pemberdayaan Desa; Tata Kelola Administrasi; Profil Desa

\begin{abstract}
This community service aims to (1) identify and compile an integrated and easy-to-use database of the Dungsuru village, and (2) compile an updated village profile document that can be used as a base for development planning in the villages of Pilangrejo, Nglipar, Gunungkidul Regency. The method of achieving these goals is carried out through training with interview methods, documentation and Focus Group Discussions at the village level. The results show that the program is running well and smoothly. This program is able to create village database documents and village profiles of Pilangrejo that are updated and useful for village development planning. The obstacles that arose in the early stages of the activities can be overcome with intensive mentoring methods. As for the suggestions filed from the results of this PPM program, the Village Government should be able to update the database and profile developments regularly as the data dynamics occur.
\end{abstract}

Keywords: Village Empowerment; Administrative Governance; Village Profiles

\section{PENDAHULUAN}

Urgensi ketersediaan profil desa dan kelurahan tersurat dari isi Permendagri Nomor 12 Tahun 2007, yang secara esensial profil desa dan kelurahan menjadi dasar perencanaan program-program pembangunan dan pemberdayaan masyarakat di desa/kelurahan, kecamatan, dan kabupaten (Gunawan, 2020). Oleh sebab itu, pelatihan penyusunan aplikasi profil desa dan kelurahan sangat perlu dilakukan, mengingat desa dan kelurahan 
merupakan garis terdepan penyedia data wilayahnya, yang juga akan menjadi dasar asumsi perencanaan program-program pembangunan dan pemberdayaan masyarakat baik di lingkup desa/kelurahan, kecamatan, maupun kabupaten (Novianto, et. al, 2014). Ketersediaan profil desa akan mampu menunjukkan laju perkembangan desa setiap tahunnya dalam aspek ekonomi, pendidikan, kesehatan, keamanan, dan ketertiban, serta juga mencerminkan tingkat partisipasi masyarakat dalam pembangunan. Adapun ruang lingkup profil desa terdiri dari data dasar keluarga yang meliputi identitas, potensi, serta permasalahan yang dihadapi. Sementara data potensinya meliputi kondisi geografis, potensi umum dan pengembangan, sarana prasarana, dan kelembagaan yang dimiliki desa/kelurahan (Sasono \& Dawanto, 2016). Program penyusunan data profil desa akan sangat mendukung kegiatan lomba desa, merupakan titik awal dari desa, untuk mempunyai peluang menjadi juara di tingkat nasional, dan terciptanya desa di Kabupaten menjadi Desa Mandiri (Lail, 2015).

Ketersediaan data yang valid, reliabel, dan akuntabel merupakan suatu elemen penting dalam perencanaan program pembangunan dan pemberdayaan masyarakat (Musjtari, 2019). Namun fenomena selama ini menunjukkan bahwa publikasi mengenai data desa/kelurahan yang dilakukan oleh berbagai instansi seringkali kurang akurat dan berbeda beda, serta tidak terintegrasi dengan baik sehingga masyarakat menjadi bingung mana data yang akurat (Musjtari, 2019). Disisi lain, pemerintah daerah kurang tanggap dalam pelaksanaan data profil kelurahan sehingga kegiatan pendataan, pelatihan profil kelurahan menjadi kurang sempurna dan bahkan terabaikan (Prihatmaji, 2013). Hal ini dapat dilihat dari kurangnya anggaran yang digunakan dalam kegiatan profil kelurahan, bahkan pemerintah daerah ada yang tidak peduli terhadap data profil kelurahan, (Hasanuddin, 2013).

Desa Pilangrejo, Kecamatan Nglipar, Kabupaten Gunungkidul belum memiliki database desa yang valid dan dapat digunakan sebagai acuan kebijakan teknis di Desa Pilangrejo. Hal ini sebagaimana yang disampaikan oleh Kepala Urusan Perencanaan Desa Nglipar yang mengatakan bahwa

"Desa Pilangrejo belum memiliki database kependudukan yang resmi. Selama ini administrasi pemerintahan dilakukan menggunakan data dari berbagai sumber sesuai dengan kebutuhan desa" (Wawancara pada observasi pertama, 19 Desember 2019)

Tidak adanya standarisasi sumber data memberikan dampak langsung dalam tata kelola pemerintahan desa. Ketidak-tersediaan data juga acap kali menghambat distribusi kebijakan yang menyangkut langsung kepada masyarakat. Membangun administrasi desa hendaknya dilakukan pada tingkatan di bawah desa yaitu dusun dan RT.

Desa Pilangrejo terdiri dari 7 (tujuh) padukuhan, yaitu Padukuhan Pilangrejo, Padukuhan Dungsuru, Padukuhan Wotgalih, Padukuhan Kaligede, Padukuhan Danyangan, Padukuhan Ngangkruk, dan Padukuhan Sriten. Desa Pilangrejo terdiri dari 7 (tujuh) RW, dan 35 (tigapuluh lima) RT. Kegiatan ini fokus pada penataan administrasi dusun di Dusun Dungsuru. Berdasarkan hasil temuan observasi awal menunjukkan bahwa Dusun Dungsuru belum memiliki profil atau database dusun yang valid dan terintegrasi. Hal ini sebagaimana yang disampaikan oleh Dukuh Dungsuru yang mengatakan bahwa

"Selama ini dusun hanya
menggunakan data yang ada. Data
yang digunakan didapatkan melalui
perkiraan dan kisaran saja. Selain itu,
diperlukan penomoran rumah dan peta
dusun agar mempermudah untuk
memetakan penduduk yang tinggal di
wilayah administratif Dusun
$\begin{aligned} & \text { Dungsuru" (Hasil wawancara } \\ & \text { observasi Dukuh Dungsuru) }\end{aligned}$

Berdasarkan temuan di atas menunjukkan bahwa Dusun Dungsuru belum memiliki tata kelola administrasi dusun yang valid dan realibel. 


\section{METODE}

Konsep pembangunan pedesaan adalah aspek komprehensif yang mempertimbangkan sejumlah faktor. Istilah ini digunakan untuk mengartikan hal-hal yang membawa perubahan pada kondisi yang ada untuk kondisi yang lebih baik. Selama beberapa dekade, konsep pembangunan pedesaan hanya berfokus pada perubahan ekonomi (Dixon, 2015; Naldi et al., 2015). Tetapi pada tahap selanjutnya, konsep ini diperluas dengan mempertimbangkan kerangka ekonomi, politik, sosial, budaya, teknologi, dan psikologis masyarakat (Dixon, 2015; Naldi, et al., 2015; Bhatia \& Kiran, 2016; Singh, 2017). Dengan kata lain, ketika fokus pada pembangunan pedesaan, tidak hanya mempertimbangkan, pengembangan infrastruktur tetapi juga focus pada pembangunan ekonomi, pembangunan manusia yang berbasis kearifan lokal (Nica, 2015; Singh, 2017; Gupta \& Rana, 2018). Berdasarkan permasalahan mitra, program Tata Kelola Administrasi Dusun Dungsuru dapat dirumuskan dalam beberapa tahapan sebagai berikut:

1. Observasi awal untuk memetakan permasalahan mitra.

Pemetaan permasalahan mitra ini dilakukan dengan cara focuss group discussion (FGD) dengan tokoh masyarakat, kepala dusun dan juga aparatur desa setempat. Selain itu, juga dilakukan wawancara secara mendalam dengan Kepala Urusan Perencanaan Desa Pilangrejo dan beberapa masyarakat untuk mendapatkan informasi yang lebih mendalam terkait permasalahan yang mitra sedang hadapi.

\section{Kolaborasi dengan stakeholder lain}

Kolaborasi dengan stakeholder lain dilakukan dalam bentuk kerjasama dalam penyelenggaraan program-program pengabdian masyarakat khususnya dalam tata kelola administrasi Dusun Dungsuru. Adapun pihak-pihak yang dilibatkan adalah Tim pelaksana, Mahasiswa, Perangkat Dusun Dungsuru, Pemerintah Desa Pilangrejo, dan Masyarakat Dusun Dungsuru.
3. Pelaksanaan Program Kegiatan: Kegiatan

Pemberdayaan Masyarakat ini dilaksanakan melalui beberapa kegiatan, yaitu: a. Pembuatan database Dusun Dungsuru, yang meliputi informasi umum dan informasi demograpi Dusun Dungsuru; b. Pembuatan Peta Dusun; dan c. Penomoran Rumah Warga Dusun Dungsuru.

\section{Monitoring dan Evaluasi}

Tim inti pelaksana melakukan monitoring setidaknya 2 kali dalam 1 periode program pengabdian masyarakat tersebut. Selain proses monitoring, juga dilakukan evaluasi programprogram yang telah dilakukan.

\section{HASIL DAN PEMBAHASAN}

1. Pembuatan Database Dusun Dungsuru

Dilihat dari masalah yang dialami oleh masyarakat Dusun Dungsuru terdapat masalah terkait Administrasi di Padukuhan Dungsuru. Berdasarkan hasil observasi minimnya pengetahuan masyarakat dalam pembuatan proposal, pembukuan, serta data seluruh warga Padukuhan Dungsuru. Pembuatan database kependudukan ini dilakukan secara digital guna membuat tata kelola administrasi kependudukan di Dusun Dungsuruh menjadi efektif dan efisien.

Adapun langkah-langkah yang dilakukan oleh tim yaitu : Pengumpulan informasi yng disimpan di dalam komputer secara sistematik sehingga dapat diperiksa menggunakan suatu program komputer untuk memperoleh informasi dari basis data tersebut, kemudian database tersebut akan diserahkan kepada pihak Dusun. Proses dalam pengambilan database diawali dengan membuat form yang berisi biodata di setiap kepala keluarga yang ada di Dusun Dungsuru. Setelah pembuatan form, tim mulai melakukan pengambilan data dengan menggunkan form menggunakan metode pembagian kelompok yang disebar ke beberapa RT $(1,2,3,4,5,6)$. Setelah mendapatkan data tersebut, tim mengolah data yang telah didapat dengan menggunkan Microsoft Excel. Adapun bentuk luaran dari program ini adalah seperti pada gambar 1 . 


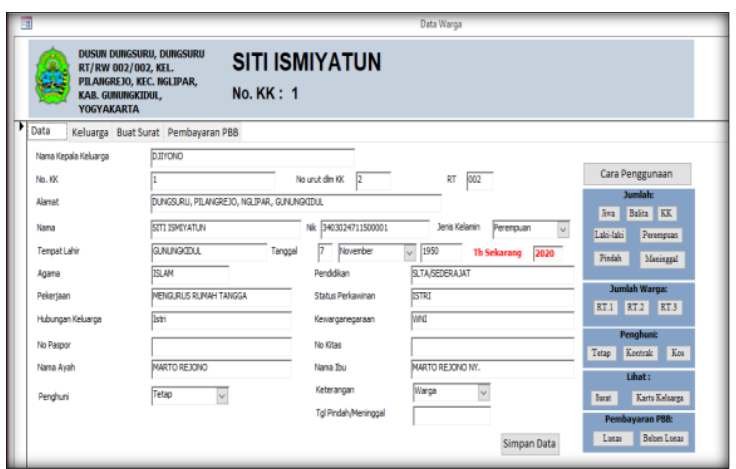

Gambar 1. Digitalisasi Database Kependudukan

Pembuatan Database berlangsung selama 25 hari. Dimulai dari penyuluhan program kerja di Balai Dusun Dungsuru. Penyuluhan program kerja ini salah satunya ingin menyampaikan bagaimana proses pembuatan Database kependudukan. Tentunya program ini tidak mungkin terjadi tanpa adanya persetujuan dari seperangkat desa maupun tokoh masyarakat di Dusun Dungsuru. Respon masyarakat untuk program database ini sangat positif, karena program ini sangat membantu masyarakat Dusun Dungsuru dalam hal administrasi guna keberlangsungan Lomba Desa yang diadakan pada bulan Maret 2020.

\section{Penomeran Rumah Masyarakat Dusun Dungsuru \\ Dilihat dari persoalan administrasi di} Dusun Dungsuru, penomoran rumah adalah salah satu persoalan yang dialami. Untuk memastikan keabsahan data tersebut, sebelum memulai penomoran tim melakukan pengambilan data informasi tentang warga sesuai dengan format KK serta melakukan pemetaan Dusun Dungsuru. Adapun output program penomoran rumah adalah seperti pada gambar 2.

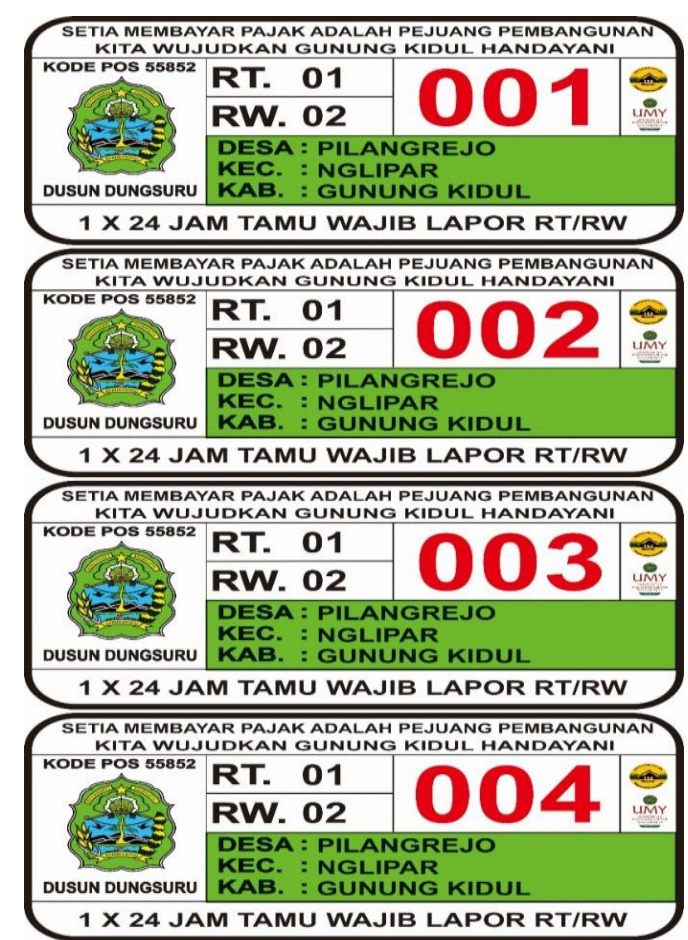

Gambar 2. Penomoran Rumah

Proses dalam penomoran rumah, hal yang dilakukan pertama yaitu, dilihat dari masalah yang berada di lapangan mengenai banyaknya data yang tidak sama dengan data yang ada saat ini (setelah tim melakukan observasi pendataan secara langsung) seperti, adanya pembangunan rumah baru yang belum terdata serta banyaknya KK tempel yang belum terdata. Kedua, beberapa rumah yang masih memiliki lokasi yang tidak sesuai dengan RT nya masing-masing. Oleh karena itu tim meminta bantuan kepada setiap ketua RT yang bersangkutan untuk membantu proses pendataan di setiap RT nya. 


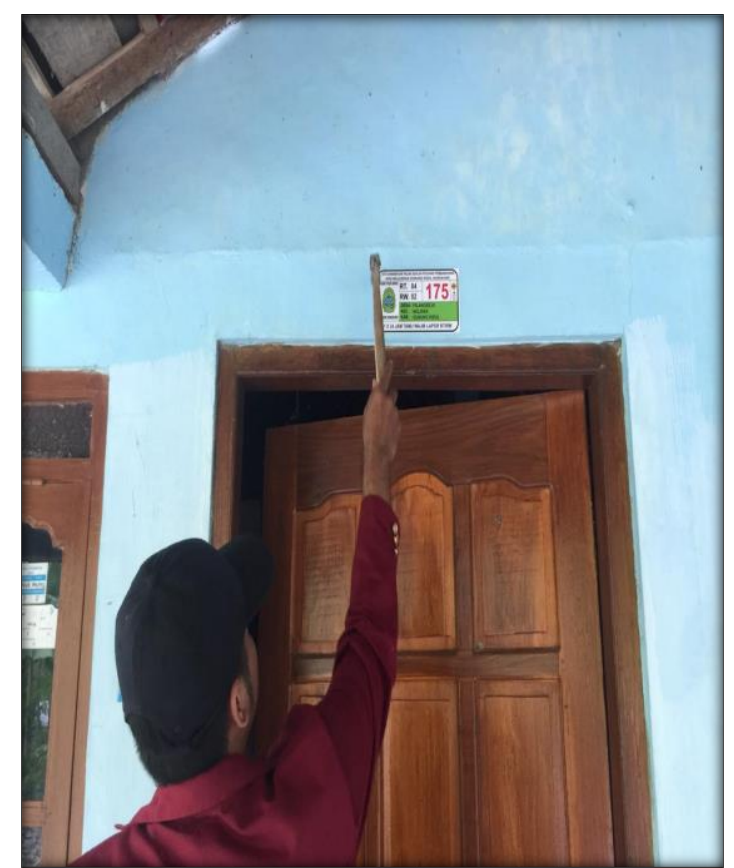

Gambar 3. Proses Pemasangan Penomoran Rumah

Respon masyarakat untuk program penomoran rumah ini sangat antusias dan berjalan dengan baik di Dusun Dungsuru. Program ini sangat membantu masyarakat untuk memperjelas identitas alamat rumah. Hal tersebut dikarenakan selama ini masyarakat merasa kesulitan dalam mencari alamat kerabatnya yang berada di Dusun Dungsuru.

3. Pembaharuan Mapping Dusun Dungsuru Program pembuatan peta ini dilakukan untuk memfasilitasi masyarakat luas dalam mengetahui keberadaan lokasi-lokasi penting maupun lokasi rumah warga yang berada di Dusun Dungsuru. Tim melakukan pembuatan peta ini guna menindaklanjuti dari program sebelumnya yaitu penomoran rumah. Gambar 4 merupakan output luaran yang dari program ini.

Proses dalam program pembuatan peta di Dusun Dungsuru ini memakan waktu 15 hari. Pertama, setelah mendapatkan data yang valid melalui program kerja sebelumnya yaitu database dan penomoran rumah. Pada akhirnya tim memiliki gambaran jelas untuk memperbaharui peta yang sudah ada sebelumnya. Kedua, dalam proses pengambilan data dijumpai beberapa kendala antara lain adanya bangunan baru yang tidak ada di peta lama, dan banyaknya kesalahan pada peta yang lama sehingga mempersulit tim dalam proses pembuatan peta. Ketiga, dalam proses pembuatan peta digital kami mendesain peta dari awal dengan konsep yang sama tetapi kami memberikan perubahan yang lebih detail pada peta. Seperti beberapa rumah yang letaknya diperbaharui karena dipeta sebelumnya rumah tersebut belum tercantum, ada beberapa tata letak rumah yang masih salah. Untuk mempermudah penyampaian informasi kami menambahkan simbol bintang pada keterangan di peta untuk menandakan masyarakat yang menggunakan KK tempel.

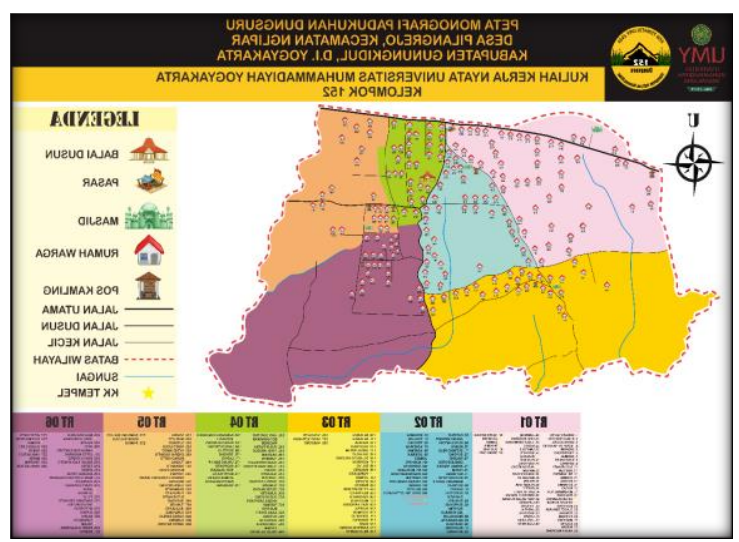

Gambar 4. Output Peta Dusun Dungsuru

\section{SIMPULAN}

Program pengabdian Penyusunan Database dan Profil desa Pilangrejo, Nglipar, Gunungkidul telah berjalan baik dan lancar. Program ini mampu menciptakan database dusun terintegrasi beserta profil desa yang update. Program PPM yang diselenggarakan mampu memberi manfaat kepada Desa Pilangrejo berupa Dusun dan Desa memiliki database kependudukan yang terintegrasi yang memudahkannya dalam mencari data, mengidentifikasi maupun menganalisis data yang tersedia update terkait dengan kebijakan yang akan diformulasikan. Selain itu, Desa memiliki data profil penduduk dan sosial ekonomi yang bermanfaat untuk pelaporan, sosialisasi dan mendukung tertib adinistrasi untuk mengikuti lomba desa. 


\section{DAFTAR PUSTAKA}

Bhatia, A., \& Kiran, C. Rural development through E-Governance initiatives in India. IOSR Journal of Business and Management (IOSR-JBM), Special IssueAETM, 16, 61-69 (2016).

Dixon, C. Rural development in the third world. Routledge (2015)

Gunawan, B. Pembentukan Administrasi Dusun Serta Pemasaran Industri Makanan Di Dusun Mangiran Bantul Yogyakarta. Qardhul Hasan: Media Pengabdian Kepada Masyarakat, 6(1), 49-56 (2020).

Gupta, A. S. N., \& Rana, S. Unlocking the Enigma of e-Governance in Rural Areas in Perspective to State of India. In Proceedings on International Conference on Emerg (Vol. 2, pp. 67-73) (2018).

Lail, J. Pembuatan Profil Dukuh Sentono. Asian Journal of Innovation and Entrepreneurship, 4(2), 109-111 (2015).

Musjtari, D. N. Pembangunan Kesadaran Hukum Masyarakat Di Dusun Jetis, Desa Jetis, Kecamatan Saptosari, Kabupaten Gunung Kidul. Jurnal Abdimas, 22(2), 151-160. (2019).

Naldi, L., Nilsson, P., Westlund, H., \& Wixe, S. What is smart rural development?. Journal of rural studies, 40, 90-101 (2015).

Nica, E. ICT innovation, internet sustainability, and economic development. Journal of Self-Governance and Management Economics, 3(3), 24-29. (2015).

Noviyanto, F., Setiadi, T., \& Wahyuningsih, I. Implementasi Sikades (Sistem Informasi Kependudukan Desa) Untuk Kemudahan Layanan Administrasi Desa Berbasis Web Mobile. Jurnal Informatika Ahmad Dahlan, 8(1), 101999 (2014).

Prihatmaji, Y. P. Pembuatan Profilisasi Dusun. Asian Journal of Innovation and Entrepreneurship, 2(01), 14-19 (2013).

Sasono, D., \& Darwanto, A. Administrasi Desa Online Desa Nogosari Kecamatan Ngadirojo Kabupaten Pacitan. JPM17:
Jurnal Pengabdian Masyarakat, 2(01) (2016).

Singh, S. K. ICT for Rural Development: An Inclusive Framework for eGovernance. The International Journal of Indian Psychology, Volume 4, Issue 2, No. 87, 70 (2017). 